\title{
KINETICS OF GROWTH OF Leishmania (Leishmania) chagasi CYCLE IN McCOY CELL CULTURE
}

\author{
Yeda L. NOGUEIRA(1), Paulo M. NAKAMURA(2) \& Eunice A. B. GAlati(1)
}

\begin{abstract}
SUMMARY
The kinetics of growth of Leishmania performed in vitro after internalization of the promastigote form in the cell and the occurrence of the transformation of the parasite into the amastigote form have been described by several authors. They used explants of macrophages in hamster spleen cell culture or in a human macrophage lineage cell, the U937. Using microscopy, the description of morphologic inter-relationship and the analysis of the production of specific molecules, it has been possible to define some of the peculiarities of the biology of the parasite. The present study shows the growth cycle of Leishmania chagasi during the observation of kinetic analysis undertaken with a McCoy cell lineage that lasted for a period of 144 hours. During the process, the morphologic transformation was revealed by indirect immunofluorescence (IF) and the molecules liberated in the extra cellular medium were observed by SDS-PAGE at 24-hour intervals during the whole 144-hour period. It was observed that in the first 72 hours the promastigote form of $L$. chagasi adhered to the cell membranes and assumed a rounded (amastigote-like) form. At 96 hours the infected cells showed morphologic alterations; at 120 hours the cells had liberated soluble fluorescent antigens into the extra cellular medium. At 144 hours, new elongated forms of the parasites, similar to promastigotes, were observed. In the SDS-PAGE, specific molecular weight proteins were observed at each point of the kinetic analysis showing that the McCoy cell imitates the macrophage and may be considered a useful model for the study of the infection of the Leishmanial cell binomial.
\end{abstract}

KEYWORDS: Leishmania chagasi; Growth kinetics: Cell culture; Soluble antigens; Amastigote; Promastigote: McCoy Cell lineage.

\section{INTRODUCTION}

The Leishmania in vitro culture contributes considerably to our knowledge of the parasite's biology 24 . In its development cycle, Leishmania presents under two different aspects, the flagellar one, named promastigote, that survives extracellularly and is found in the intestinal tract of the vector (Phlebotominae) and the intracellular one, known as amastigote, present in the macrophages, in the bone-marrow and in cells of the endoplasmic reticle of the mammal host ${ }^{24}$.

The amastigotes have been described in cell cultures ever since this technique began to be used ${ }^{14,25,30}$. Many experiments have been undertaken using the infection of Leishmania donovani and Leishmania infantum in hamster spleen cell explants ${ }^{21}$, macrophages and fibroblasttype cells in culture. It has also been shown that Leishmania may be transmitted from infected cells to uninfected ones and the $L$. donovani morphological change in a pure macrophage culture in comparison with a cell culture mixing macrophage and fibroblast-type cells in the same culture flask ${ }^{16}$ has been reported.

Other researchers ${ }^{6,16,25}$ have also reported that flagellar forms (promastigotes) infecting chicken embryo or human amnion cell cultures have been transformed into amastigotes within 48 hours.

The mammal cell invasion by the flagellar form of Leishmania has been documented by the cinemacromicrographic technique ${ }^{25}$.

Growth kinetic analyses made after the promastigotes internalization in the cells and their transformation into amastigotes have been made by several authors ${ }^{6,11,13,15,22}$ who have also demonstrated the host-parasite relationship and so contributed to the comprehension of the biology of these protozoa.

The use of co-focal microscopy has allowed the description of the inter-relation between the morphological changes and the synthesis of the specific molecules induced by the intracellular amastigote into the degradation of the MHC class II, thus suggesting the escape mechanism that the parasite presents when in the amastigote form and by which it avoids the presentation of antigen to the CD4 and CD8 cells ${ }^{1}$.

At the present level of knowledge, therefore, the growth of Leishmania in vitro, using macrophage explants obtained from hamster

(1) Departamento de Epidemiologia, Faculdade de Saúde Pública/Universidade de São Paulo, São Paulo, SP, Brasil.

(2) Instituto Adolfo Lutz, Divisão de Biologia Médica, Seção de Sorologia, São Paulo, SP, Brasil.

Correspondence to: Yeda L. Nogueira, Departamento de Epidemiologia, Faculdade de Saúde Pública/Universidade de São Paulo, Av. Dr. Arnaldo 715, 01246-902-São Paulo, SP, Brasil. E-mail: ynogueir@usp.br 
spleen cells or from the U937 macrophage lineage cells, provides important models for research into the cellular and molecular biology of the parasite cycle and immune response induction.

The present study aims to show the infection of McCoy cells by promastigotes of Leishmania chagasi as well as the morphologic alterations of Leishmania and of the cells during 144-hour observation of the kinetic analysis and demonstrate that McCoy cells imitate macrophages and may be useful as a model of the Leishmania/host interaction.

\section{MATERIAL AND METHODS}

Promastigotes of Leishmania: produced in conditioned growth medium of McCoy cells culture ${ }^{19}$, according to the methodology described $^{22}$.

Promastigotes strain: promastigote forms of Leishmania (Leishmania) chagasi were cultivated in semi-solid Novy-McNealNicolle medium (NNN medium), using a strain obtained from a dog with visceral leishmaniasis from the State of Mato Grosso do Sul (Brazil), registered at strain bank of Instituto Oswaldo Cruz \# L 2665 and classified as MCAN/BR/2002/LVV/136 BR, MS, CAMPO GRANDE.

Conditioned growth medium (CGM): Eagle's medium supplemented with 5\% foetal calf serum (FCS) used for the growth McCoy cells ${ }^{19}$. After the cells' growth the medium having the excretion of metabolites is considered "conditioned".

Passages in conditioned growth medium: Promatigotes grown in NNN medium was inoculated in conditioned medium. The inoculum was a $10 \mu \mathrm{L}$ harvest from a solution with $10^{4}$ parasites $/ \mathrm{mL}$ and kept in $2.5 \mathrm{~mL}$ CGM (24 wells tissue culture plates) and its multiplication was observed for five days (120 hours). After day 5, the medium was saturated with the flagellate forms of the parasite (promastigotes). Soon afterwards, successive passages were made by inoculating aliquots with $2 \times 10^{4}$ promastigotes $/ \mathrm{mL}(25 \mathrm{~mL})$ plus $(25 \mathrm{~mL})$ of conditioned growth medium in $100 \mathrm{~cm}^{3}$ bottles at room temperature $\left(25-27{ }^{\circ} \mathrm{C}\right)$.

McCoy lineage cells: obtained from the cell collection of the Instituto Adolfo Lutz - Secção de Culturas Celulares. The cells were grown in monolayers in Eagle medium supplemented with $5 \%$ foetal calf serum (FCS).

Kinetics of infection: were performed on plaques with 24 wells containing recently split McCoy cells and with little coverslips inside each well. Promastigotes were added to half of the wells and in the other half only the monolayer of the McCoy cells has maintained to act as control for each point of the kinetic analysis. The plaque was incubated at $37{ }^{\circ} \mathrm{C}$ and four wells were chosen each 24 hours, the growth of their cells interrupted, the supernatant removed and the cells fixed with a $2 \%$ formaline solution, two of the well being inoculated with promatigotes and two kept as control. This procedure was continued on for 144 hours (six days).

Analysis of kinetics: all the coverslips were revealed with immunofluorescent technique using a pool of positive sera obtained from symptomatic for visceral leishmaniasis dogs and fluorescein marked anti-dog conjugate from the kit produced by Biomanguinhos (lot \# 024CF005Z). After reaction each coverslip was observed under an epifluorescent microscope with an enhancement of 400x and 1000x and several fields were photomicrographed. The counting and the observation of the reproduction of the cellular cycle were followed by the analysis of the photos taken at 24 hour intervals.

Analysis of the proteins released in the extra-cellular medium: aliquots of the extra-cellular medium were collected at 24 hour intervals, analyzed in electrophoresis gel SDS-PAGE at a concentration of $12 \%$ of acrylamide and stained with bromophenol blue, the electrophoretic run being undertaken by the technique originally described ${ }^{17}$.

\section{RESULTS}

Figure 1 illustrates the kinetic analysis of the $L$. chagasi cycle after the inoculation of 100 promastigotes/10 $\mu \mathrm{L}$ in each well with McCoy cells spread in monolayer. Morphologic changes were observed during the period 24 to 72 hours: the Leishmania presented a rounded shape and adhered to the cellular membrane (Figs. 1-A, 1-B and 1-C); in Figure 1-D it is seen that the Leishmania have been internalized and the cellular membrane presented some alteration; in Figure 1-E small particles that react to the immunofluorescence have been liberated into the extra-cellular medium - this is to be seen in the 120-hour material. Flagellate forms may be seen in the extra-cellular medium in the material from 144 hours (Fig. 1-F). Figure 2 shows the formation of vacuoles (parasitophores) inside the McCoy cells. Figure 3-A shows the electrophoresis run in SDS-PAGE gel of the extra-cellular fluid in each point of the kinetics. It is possible to see the presence of one band above the bovine serum albumin (BSA) with molecular weight (MW) of approximately $70 \mathrm{kDa}$ which occurs from 72 until 144 hours; this band cannot be observed in the seventh lane i.e., the control lane (extracellular fluid from uninfected cells).

In Figure 3-B a heterodispersed band may be observed between 59

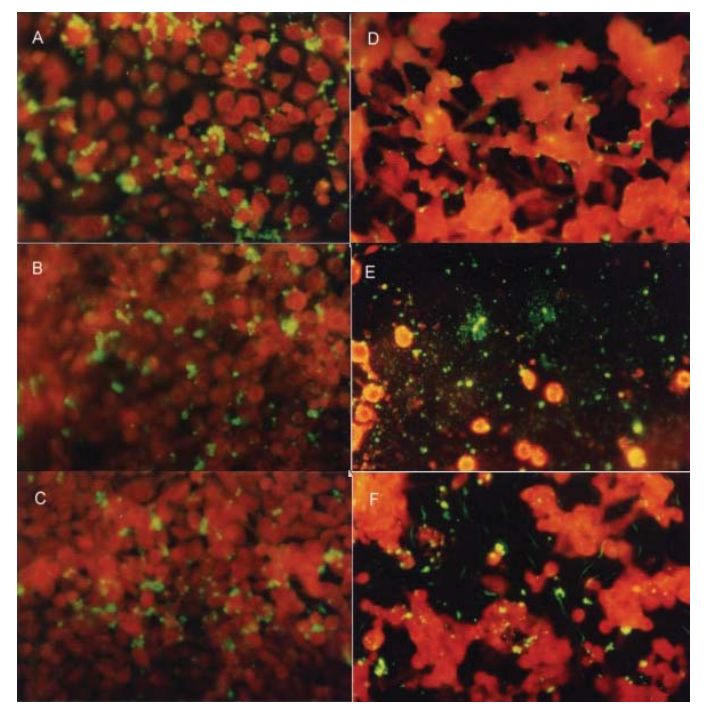

Fig. 1 - Kinetic growth of L. chagasi in McCoy cell lineage. 1 (A) 24 hours; 1(B) 48 hours; 1(C) 72 hours; 1(D) 96 hours; 1(E) 120 hours and 1(F) 144 hours. 


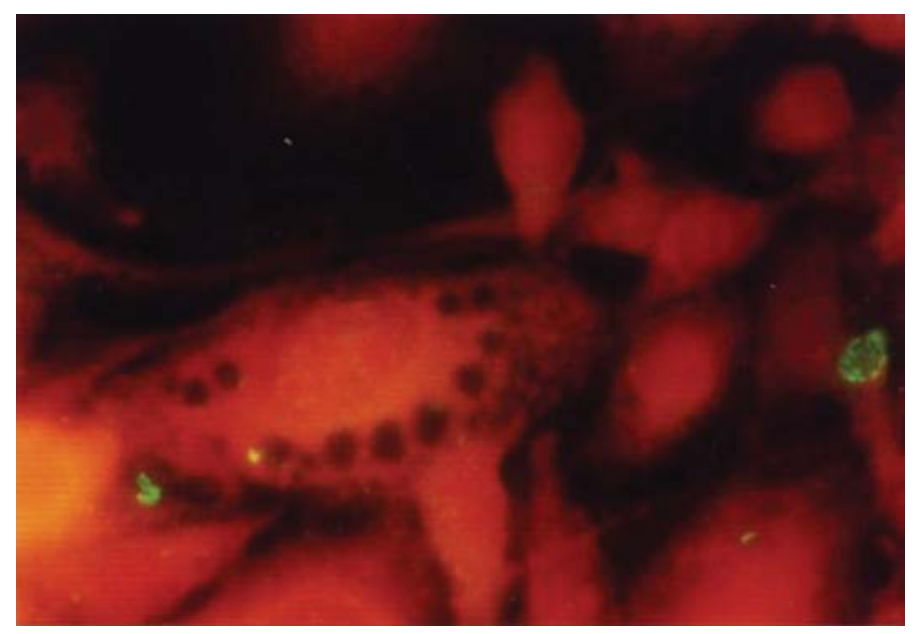

Fig. 2 - Parasitophorous presents post-infection with L. chagasi in McCoy cell lineage.

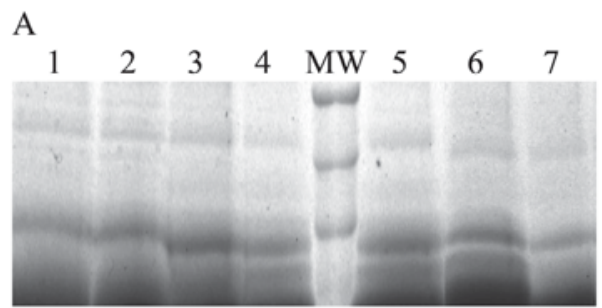

$-70 \mathrm{kda}$

$-66 \mathrm{kDa}$

B

$63 \mathrm{kDa}-$

$55 \mathrm{kDa}-$

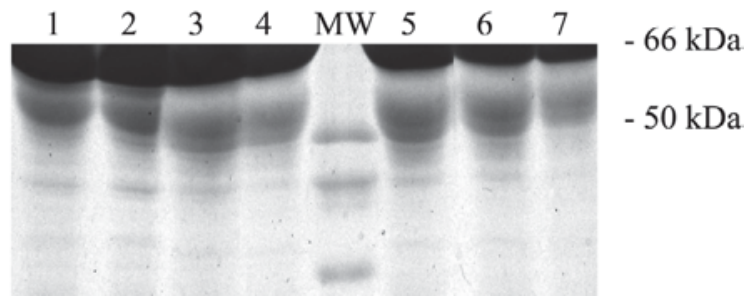

Fig. 3 - Gel SDS-Page electrophoresis from extra-cellular fluid at each point in the kinetic growth. Lane (1) 24 hours; Lane (2) 48 hours; Lane (3) 72 hours; Lane (4) 96 hours; MW (standard molecular weights); Lane (5) 120 hours; Lane (6) 144 hours and Lane (7) cell control without $L$. chagasi inoculation.

and $63 \mathrm{kDa}$. This band, just below the BSA, under lanes 1 and 2, was obtained at 24 and 48 hours respectively. Meanwhile at 72 and 96 hours (lanes number 3 and 4) the concentration diminishes. A band of constant concentration heterodispersed with MW between 50 and 55 $\mathrm{kDa}$ (in lanes 1 through 3 ) that corresponds to 24 through 72 hours may also be observed. This band concentration diminishes (in lane 4) at 96 , but in 120 hours (lane 5) it is seen to have returned and been maintained up to 144 hours (lane 6). In lanes 1 to 6 a constant band with molecular weight of around $45 \mathrm{kDa}$ may be observed. The seventh lane corresponds to extra-cellular growth medium of a culture uninfected with the parasite.

\section{DISCUSSION}

The follow-up of the morphologic alterations of the L. chagasi flagellar form (promastigote) through the growth kinetics in McCoy lineage cells, for 144 hours (six days) at $37^{\circ} \mathrm{C}$, showed that in the first 24 hours all the promastigotes assumed rounded form and continued to adhere to the cellular membranes and, on the $6^{\text {th }}$ day after inoculation, new flagellate forms were observed in the extra-cellular medium. These alterations were also found in an axenic culture of the amastigotes from clone $L d$ 1S-CL2D of $L$. donovani in macrophage U937 cell lineage ${ }^{12}$. The same authors observed that after the promastigote adaptation the clone $L d$ 1S-CL2D assumed the amastigote-like phenotype, able to propagate continuously in this amastigote form (LdAxAm). In these cells the $L$. donovani were able to switch from amastigote to promastigote phenotype, depending on alterations in the condition of the medium. Alterations in certain protein and protease concentrations due to the different concentrations of amastigote and promastigote forms and proteins expressed by the gene $\mathrm{A} 2$ were also demonstrated $^{12}$.

Aflagellate parasites rounded in form and adhering to the cells were observed at the kinetic points between 24 and 72 hours, in the present research (Fig. 1A, 1B and 1C). The cells in infected medium were seen, until 96 hours, to have swollen (as compared with cells in the control medium) and no rounded forms were seen to have adhered to the membrane. Smaller, also rounded, forms were being expelled from the cells' interior. The hypothesis that the parasite had entered the cell is sustained by Figure 2 where parasitophores, similar to those shown in macrophages formed in the interior of the McCoy cell, were observed $^{12}$.

This evidence corroborates the view that the Leishmania modifies its biochemistry in order to maintain its digenetic form ${ }^{24}$.

Evidences were that the glycoprotein GP63 ${ }^{28}$ favors the adherence to the macrophage ${ }^{28}$ and contributes to the Leishmania survival in the interior of the phagolysosome that is formed inside the macrophage $\mathrm{e}^{10,26,27}$. The GP63 from the promastigote anchors itself in the macrophage surface through the GPI ${ }^{8,13,28}$. There are reports indicating that the amastigote tissue of L. mexicana shows reduced amounts of GP63 when compared to other cellular proteins and that this molecule in L. mexicana, is reduced to the flagellar pocket and works like an anchorage protein GPI ${ }^{19,20}$. It was also found a low level of glycoprotein GP63 in L. chagasi amastigotes produced in U937 cells ${ }^{28}$. This same author noticed too ${ }^{28}$ the presence of two isoform GP63 (63 kDa and $59 \mathrm{kDa}$ ) that predominate in the promastigote and when this form penetrates the macrophage and became amastigote, a new isoform appers, the GP63, with $64 \mathrm{kDa}$. Other observations were made relating to the expression of heat shock proteins (hsp70 and hsp90) when the promastigotes are converted to amastigotes after exposure at $37{ }^{\circ} \mathrm{C}$. In U937 cells the expression of the proteins hsp70 and hsp90 increases during the first 24 hours after the parasite has entered the cells; afterwards they return to their initial conditions at around 140 hours after the infection.

Although promastigotes have been observed in extra-cellular medium at the 144 hours (the $6^{\text {th }}$ day), of the kinetics at $37{ }^{\circ} \mathrm{C}$, it is impossible to know if these forms were due only to the complete cycle of entering and leaving the cell or if, besides that, have occurred the co-existence of two simultaneous events, i.e., the promastigote forms found in the extra-cellular medium would be the amastigote-like form 
that had not entered the cells and which were forced by the changes in the medium to return to the flagellar form ${ }^{31}$, even if the flagellar form at $37{ }^{\circ} \mathrm{C}$ cannot be explained. Others authors ${ }^{2,31}$ also point out that the modifications in Leishmania morphology due to biochemical occurred as a result of alterations in the medium and temperature. Thus, new promastigote forms originated from amastigotes due to lesions and put into HOMEM medium demonstrated adaptation to the axenic medium $^{14,18}$. It has also been reported that amastigotes obtained from infected CBA mice were transformed in promastigotes ${ }^{11}$. The amastigotes were immersed in HOMEM medium supplemented with $10 \%$ FCS and incubated at $25^{\circ} \mathrm{C}$; on the $3^{\text {rd }}$ day the medium used was Schneider's supplemented with $20 \%$ FCS because this medium induces metacyclogenesis ${ }^{2}$ by the $9^{\text {th }}$ day. The subpassages were incubated at $32{ }^{\circ} \mathrm{C}$ and the metacyclic forms became amastigote-like. In the same study the authors reported the co-existence of both amastigote forms and metacyclic promastigotes at higher temperatures. BATES ${ }^{2}$ also uses the criteria analysis for the cistein-proteinases in SDS gel in order to define the patterns of promastigote forms and amastigote ones. Bands with MW from 30 and $36 \mathrm{kDa}$ are present in amastigotes and apparently absent in promastigotes, showing that these biochemical markers indicate differences between amastigotes and promastigotes of $L$. mexicana.

Researchers ${ }^{27}$ have studied the biochemical response of in vitro cultivated promastigotes with reference to the increase in temperature and confirmed that the rise in temperature promotes the rounded form and, afterwards, a form similar to amastigotes; however, they also verified that the parasite seldom survives more than a few days.

It has been seen in the present study that in the kinetics the presence of specific bands occurs: one with MW around $45 \mathrm{kDa}$ throughout the process (lines 1 to 6 ) and another heterodispersed band from 63 to 59 $\mathrm{kDa}$ during the period from 24 to 72 hours. There is yet another band with MW of $70 \mathrm{kDa}$ at 72 hours that remains until 144 hours. These bands would be in accordance with the presence of amastigote and promastigote forms throughout the kinetics, as may be seen in the photos; Figures 1A, 1B and 1C during the first 72 hours, the inoculated promastigote forms should be transformed into amastigote-like forms adhering to the cell membranes. According to other authors ${ }^{5,28}$ the presence of a GP63 could show the Leishmania adherence to the cells. These forms diminish in quantity and enter the cells when the $70 \mathrm{kDa}$ band becomes evident and this would be equivalent to the shock protein (hsp70) which induces the transformation of the promastigote into amastigote forms at $37^{\circ} \mathrm{C}^{28}$. Meanwhile the presence of promastigotes in extra-cellular medium at $37^{\circ} \mathrm{C}$ on the $5^{\text {th }}$ day (at 120 hours) is a rather obscure point that needs further study to come though to a more adequate conclusion regarding this transformation. According to BEETHAM et al. ${ }^{5}$ the GP46 should be present in greater concentration in the procyclic promastigotes during the logarithmic phase of growth, while in the stationary phase the presence of the metacyclic form would be commoner and the intense exchange of the surface protein GP46 should occur often.

The GP63 and the lipophosphoglycan (LPG) are two other surface molecules also involved in metacyclogenesis ${ }^{29}$. These molecules would be associated for the protection of promastigotes against decomposition by the complement, favoring the phagocytosis process by the macrophage $e^{9,28}$ which strengthens the clearer presence of a band with a MW of approximately $63 \mathrm{kDa}$ in the two first lanes of Figure 3B and if Figures $1 \mathrm{~A}$ and $1 \mathrm{~B}$ can be associated it is observed that a larger concentration of Leishmania adhered to the surface of the cell membrane.

Other heterodisperse band of MW 50 and $55 \mathrm{kDa}$ was observed that matches with strong alterations in cellular morphology. It has not yet been possible to identify if this band would be linked to the tumoral necrosis factor $(\mathrm{TNF})^{7}$ which is an important marker involved in the process of Leishmania infection in macrophages, but this is a hypothesis worth to be tested in future studies.

In further study the same growth kinetics will be evaluated in the quest for a better characterization of the markers liberated during the kinetics in the extra-cellular medium as there is no possible doubt about the relationship between these biochemical markers and the morphologic alterations observed in L. chagasi.

Concrete results which allow several aspects of Leishmania in vitro to be questioned and identify the McCoy cell lineage as a possible and promising model to follow Leishmania development and growth have been achieved by this research project.

\section{RESUMO}

\section{Cinéticas de crescimento do ciclo da Leishmania (Leishmania) chagasi em cultura de células McCoy}

Cinéticas de crescimento de Leishmania realizadas in vitro após a internalização da forma promastigota na célula e a ocorrência da transformação do parasito na forma amastigota foram descritas por vários autores, seja com a utilização de explantes de macrófagos em células de baço de hamster ou atualmente da célula de linhagem de macrófago humano U937. Aliando a microscopia à descrição das interrelações morfológicas e à síntese de moléculas específicas foi possível esclarecer pontos sobre a biologia do parasito.

O presente estudo mostra o acompanhamento do ciclo de crescimento da Leishmania chagasi em uma cinética realizada com células de linhagem McCoy, no período de 144 horas.

Durante o processo, as transformações morfológicas foram reveladas pela reação de imunofluorescência indireta (RIFI) e as moléculas liberadas no meio extracelular foram observadas pelo método de SDS-PAGE, em intervalos de 24 horas no período de 144 horas.

Observou-se que nas primeiras 72 horas, a forma promastigota da L. chagasi fica aderida à membrana das células com aspecto arredondado (amastigota-like). Em 96 horas as células infectadas apresentaram alterações morfológicas; em 120 horas, as células liberaram, para o meio extracelular, antígenos fluorescentes solúveis; e em 144 horas foram observadas novas formas alongadas dos parasitos como se fossem promastigotas. No SDS-PAGE, proteínas com pesos moleculares específicos são observadas em cada ponto da cinética, mostrando que a célula McCoy parece mimetizar o macrófago e que pode ser um modelo útil para o estudo da infecção do binômio leishmânia/célula. 

$341,2006$.

\section{ACKNOWLEDGEMENTS}

We are grateful to Maria Elizabeth Carvalheiro Dorval, Universidade Federal de Mato Grosso do Sul, who donated the Leishmania (Leishmania) infantum chagasi strain isolated from a dog in Mato Grosso do Sul state and to Maria Dulce Bianchi Rosa for technical assistance, Tropical Diseases Laboratory, Epidemiology Department of Faculdade de Saúde Pública, University of São Paulo.

\section{REFERENCES}

1. ANTOINE, J-C.; LANG, T.; PRINA, E.; COURRET, N. \& HELLIO, R. - H-2 molecules, like MHC class II molecules, are target to parasitophorus vacuoles of Leishmaniainfected macrophages and internalized by amastigotes $L$. amazonensis and $L$. mexicana. J. Cell Sci., 112: 2559-2570, 1999.

2. BATES, P.A.; ROBERTSON, C.D.; TETLEY, L. \& COOMBS, G.H. - Axenic cultivation and characterization of Leishmania mexicana amastigote-like forms. Parasitology, 105: 193-202, 1992.

3. BATES, P.A. - Complete developmental cycle of Leishmania mexicana in axenic culture. Parasitology, 108: 1-9, 1994.

4. BEETHAM, J.K.; MYUNG, K.S.; McCOY, J.J.; WILSON, M.E. \& DONELSON, J.E. Glycoprotein 46 mRNA abundance is post-transcriptionally regulated during development of Leishmania chagasi promastigotes to infectious form. J. biol. Chem., 272: 17360-17366, 1997.

5. BEETHAM, J.K.; DONELSON, J.E. \& DAHLIN, R.R. - Surface glycoprotein PSA (GP46) expression during short-and long-term culture of Leishmania chagasi. Molec. Biochem. Parasit., 131: 109-117, 2003.

6. BELLE, E.A. Canad. med. Ass. J., 79: 726-728, 1958 apud HERMAN, R. - Studies of the numbers and morphology of intracellular form of Leishmania donovani grown in cell culture. J. Protozool., 13: 408-418, 1966.

7. BIRKLAND, T.P.; SYPEK, J.P. \& WYLER, D.J. - Soluble TNF and membrane TNF expressed on CD4+ T lymphocytes differ in their ability to activate macrophage antileishmanial defense. J. Leuk. Biol., 51: 296-299, 1992.

8. BORDIER, C. - The promastigote surface protease of Leishmania. Parasit. today, 3: 151-153, 1987.

9. BRITTINGHAM, A.; MILLER, M.A.; DONELSON, J.E. \& WILSON, M.E. - Regulation of GP63 mRNA stability in promastigotes of virulent and attenuated Leishmania chagasi. Molec. Biochem. Parasit.,112: 51-59, 2001.

10. CHAUDHURI, G.M.; CHAUDHURI, A; PAN, A. \& CHANG, K-P. - Surface acid proteinase (gp63) of Leishmania mexicana: a metalloenzyme capable of protecting liposome-encapsulated proteins from phagolysosomal degradation by macrophages. J. biol. Chem., 264: 7483-7489, 1989.

11. COOMBS, G.H.; HART, D.J. \& CAPALDO, J. - Leishmania mexicana: drug sensitives of promastigotes and transforming amastigotes. J. Antimicrob. Chemother., 11: 151-162, 1983.

12. DEBRABANT, A.; JOSHI, M.B.; PIMENTA, P.F.P. \& DWYER, D.M. - Generation of Leishmania donovani axenic amastigotes: their growth and biological characteristics. Int. J. Parasit., 34: 205-217, 2004

13. ETGES, R.; BOUVIER, J. \& BORDIER, C. - The major surface protein of Leishmania promastigotes is anchored in the membrane by a myristic acid-labeled phospholipide. EMBO J., 5: 597-601, 1986.
14. GRAVRILOV, W. \& LAURENCIN, S. Ann. Soc. belge Méd. trop., 18: 41-56, 1938 apud HERMAN, R. - Studies of the numbers and morphology of intracellular form of Leishmania donovani grown in cell culture. J. Protozool., 13: 408-418, 1966.

15. HAWKING, F. - Growth of Protozoa in tissue culture. V. Leishmania donovani. Trans. roy. Soc. trop. Med. Hyg., 41: 545-554, 1948.

16. HERMAN, R. - Studies of the numbers and morphology of intracellular form of Leishmania donovani grown in cell culture. J. Protozool., 13: 408-418, 1966.

17. LAEMMLI, U.K. - Cleavage of structural proteins during assembly of the head of bacteriophage T4. Nature (Lond.), 227: 680-685, 1970.

18. MALLINSON, D.J. \& COOMBS, G.H. - Biochemical characteristics of metacyclic forms of Leishmania major and L. mexicana mexicana. Parasitology, 98: 7-15, 1989.

19. McCOY CELL LINE. http://www.biotech.ist.unige.it/cldb/cat1.html [acessed 13/06/ 2005] and http://www.atcc.org catalog number = CRL 1696 [accessed 13/06/2005]

20. MEDINA-ACOSTA, E.; KARESS, R.E.; SCHWARTZ, H. \& RUSSEL, D.G. - The promastigote surface protease (gp63) of Leishmania is expressed but differentially processed and localized in the amastigote stage. Molec. Biochem. Parasit., 37: 263$273,1989$.

21. MILLER, H.C. \& TWOHY, D.W. - Infection of macrophage in culture by leptomonads of Leishmania donovani. J. Protozool., 14: 781-789, 1967.

22. NOGUEIRA, Y.L. \& GALATI, E.A.B. - Reproduction of Leishmania (Leishmania) infantum chagasi in conditioned cell culture growth medium. Rev. Inst. Med. trop. S. Paulo., 48: 147-150, 2006.

23. PAI, H. et al. Proc. Soc. exp. Biol. Med., 46: 606-608, 1941 apud HERMAN, R. Studies of the numbers and morphology of intracellular form of Leishmania donovani grown in cell culture. J. Protozool., 13: 408-418, 1966.

24. PUENTES, F.; DIAZ, D.; HOYA, R.D. et al. - Cultivation and characterization of stable Leishmania guyanensis complex axenic amastigota derived from infected U937 cells. Amer. J. trop. Med. Hyg., 63: 102-110, 2000.

25. PULVERTAFT, R.J.V. \& HOYLE, G.F. - Stages in life-cycle of Leishmania donovani Trans. roy. Soc. trop. Med. Hyg., 54, 191-196, 1960.

26. RUSSELL, D.G. \& WILHELM, H. - The involvement of the major surface glycoprotein (gp63) of Leishmania promastigotes in attachment to macrophages. J. Immunol., 136: 2613-2620, 1986

27. SHAPIRA, M.; McEWEN, J.G. \& JAFFE, C.L. - Temperature effects on molecular processes which lead to stage differentiation in Leishmania. EMBO J., 7: 28952901, 1988.

28. STREIT, J.A.; DONELSON, J.E.; AGEY, M.W. \& WILSON, M.E. - Developmental changes in the expression of Leishmania chagasi gp63 and heat shock proteins in a human macrophage cell line. Infect. Immun., 64: 1810-1818, 1996.

29. WILSON, M.E.; PAETZ, K.E.; RAMAMOOTHY, R. \& DONELSON, J.E. - The effect of ongoing protein synthesis on the steady state levels of GP63 RNAs in Leishmania chagasi. J. biol. Chem., 268: 15731-15736, 1993.

30. WEINMAN, D. - Factors affecting the morphology of Leishmania tropica . Parasitology, 31: $181-192,1939$

31. ZILBERSTEIN, D.; BLUMENFELD, N.; LIVEANU, V.; GEPSTEIN, A. \& JAFFE, C.L. - Growth at acidic $\mathrm{pH}$ induces amastigotes stage-specific protein in Leishmania promastigotes. Molec. Biol. Parasit., 45: 175-178, 1991.

Received: 16 November 2005

Accepted: 24 July 2006 